\title{
Influence of Distance Learning on the Level of Perception of New Information
}

\author{
Afanasyeva T.S. \\ Saint Petersburg University \\ of Management Technologies and Economics, \\ Saint Petersburg, Russia, \\ Herzen State Pedagogical University of Russia, \\ Saint Petersburg, Russia, \\ tafanasy@yandex.ru
}

\author{
Pokrovskaia N.N. \\ Herzen State Pedagogical University of Russia, \\ Saint Petersburg, Russia, \\ Peter the Great St. Petersburg Polytechnic University, \\ Saint Petersburg, Russia, \\ Saint Petersburg Electrotechnical University "LETI", \\ Saint Petersburg, Russia, \\ nnp@spbstu.ru
}

\author{
Grishakina N.I. \\ Yaroslav-the-Wise Novgorod State University, \\ Veliky Novgorod, Russia, \\ gnisemm@mail.ru
}

\begin{abstract}
In March 2020, general self-isolation was announced in Russia, which became necessary against the background of the pandemic caused by the Covid-19 virus. The incidence statistics for the new virus grew at a catastrophic rate, the lack of a vaccine and an effective form of treatment led to the fact that in order to reduce the risks of the spread of a dangerous infection all educational institutions of the Russian Federation have switched to distance learning. The relevance of this study is due to the fact that many universities were not ready for such a drastic change in the educational format and, unfortunately, not all were able to provide a decent level of education during this difficult period. This is due to a variety of reasons, such as, for example, the existing technical base does not meet modern requirements, the lack of digital skills among teachers, the inability to create high-quality digital content in a short time, as well as many other issues that are covered in sufficient detail in this study. Based on the analysis of the existing problems that educational institutions faced in the process of introducing distance learning, further tasks were formed that need to be paid attention to in the further construction of the educational process. These include building an educational environment that includes key players in the labor market, ensuring the sustainability of the educational process through the introduction of a blended learning system, optimizing all educational costs, and most importantly, increasing student motivation and involvement in the educational process by introducing gamification and various game learning tools.
\end{abstract}

Keywords-distance education, methods, technologies, digitalization

\section{INTRODUCTION}

Modern technologies do not stand still, and a modern higher education institution needs to pay special attention to their place in the educational process [1]. Distance learning methods [2] provide a huge range of opportunities for both teachers and students. During the transition to Russia in March 2020, due to the critical situation caused by the dangerous Covid-19 virus, higher educational institutions to distance learning, a whole range of problems was identified that were faced by both leading universities and students of all forms of education.

By the time the pandemic began, distance learning was not a novelty for the higher education system, moreover, it was enshrined at the legislative level, however, as the practice of its total application has shown, it has a whole range of shortcomings. Despite the fact that the use of distance education is enshrined at the legislative level by article 16 of the Federal Law "On Education in the Russian Federation" dated December 29, 2012 No 273-FZ, nevertheless, unfortunately, most educational institutions in Russia could not adequately cope with distance learning. education. Unfortunately, most universities, instead of high-quality distance learning, simply reoriented students to independent work. Thus, the use of distance learning and distance learning technologies in the implementation of state programs affected the quality and number of graduates, although it should have been the other way around [3].

\section{PROBLEM STATEMENT}

During the Covid-19 pandemic, the topic of effective distance learning became the number one topic, practically at all forums and conferences that took place in the spring and summer of 2020 and were dedicated to higher education. For example, at the Sevastopol Open Data 2020 Forum, leading experts and representatives of the higher education system 
discussed the problems of distance learning, which the pandemic revealed, and highlighted the points that should be paid attention to when forming curricula and work programs in the new, post-coronavirus reality. Particular attention at the forum was paid to the social adaptation of students to distance learning, and the impact of the new learning format on the perception and assimilation of new information [4].

\section{RESEARCH QUESTIONS}

3.1 How the Covid-19 pandemic has affected the higher education system?

3.2 What problems have the universities of the Russian Federation faced in organizing distance learning?

3.3 What are the main communication channels in distance learning, which, according to students, helped them to master new knowledge most effectively?

\subsection{Digital technologies in education, main trends.}

\section{PURPOSE OF THE STUDY}

The purpose of this work is to consider the main problems of distance learning in Russia in 2020, to identify the main obstacles to the perception of new information by students in the process of online learning.

One of the key problems associated with distance learning is the lack of opportunities for social contacts between students and teachers and classmates. According to expert Mikhail Myagkov, chairman of the consortium of the Open Data 2020 forum, it was the absence of "live communication" that had an extremely negative impact on both the psychological aspect [5] and the effectiveness of mastering academic disciplines. According to the expert, in the event of re-introduction of distance learning, it is necessary to take all possible measures, of course, within the framework of the legislation, to give students the opportunity to continue communication, because the university provides not only professional skills, but also contributes to the harmonious development of the individual. Full care for distance learning (following the example of Western universities) will have an extremely negative impact on society. In addition, it is necessary to actively work with the motivation and involvement of students in the educational process [6], students need to be given a clear understanding of how they can use the knowledge gained in their professional and social life [7].

According to the Foundation for the Promotion of Public Opinion Research, students and young people turned out to be the most alarming and panic stratum of the population during the Covid-19 pandemic, but at the same time they were able to quickly adapt to changes in the environment and form new requests. that relate to both learning problems and life in gen.

The lack of the necessary technical base to provide distance learning, the abrupt and unexpected transition to online education showed that, unfortunately, the majority of Russian students and teachers do not have the necessary equipment in order to provide quality classes and master new knowledge [8]. A number of universities provided their staff and students with technology, but a large percentage of students were limited only by the use of smartphones, which significantly reduced the opportunities for quality learning and lowered the rates of perception of new information.
Let's consider the main communication channels in distance learning, which, according to students, helped them to master new knowledge most effectively. The survey was conducted among students of St. Petersburg universities, in May 2020, 356 people took part in the survey, according to students, the data presented in (Table I) turned out to be the most effective for the perception of new information.

TABLE I. The Most EfFective Communication Channels in Distance LEARNING

\begin{tabular}{|l|c|}
\hline \multicolumn{1}{|c|}{ Main communication channels } & Percentage, \% \\
\hline Zoombroadcast & 56 \\
\hline Instagram streams & 47 \\
\hline Skype sessions & 33 \\
\hline Vk broadcasts & 25 \\
\hline Messengers & 20 \\
\hline
\end{tabular}

Lack of quality digital content. In a short time, university teachers had to prepare material that should help students master the necessary competencies. The problem was that classical Russian education presupposes a large enough fulltime format of education. Only a small percentage of Russian universities have introduced some types of disciplines into their work programs, which at the time of the development of the pandemic and the closure of universities were already conducted in a remote format. The task for digital content is very serious - using distance learning forms, to convey new knowledge to the student, and also to help students to master this new knowledge to the maximum.

Consider what actually happened, the colossal flow of information in which students should navigate, led to the fact that some information was simply lost or not assimilated by students. In addition, there are certain types of educational disciplines that have significantly lost in quality when moving to the online format. The problem was that lectures were usually conducted via videoconference, while practical assignments were sent and evaluated by e-mail. Interaction in the electronic environment can and should be more efficient.

Let's consider the most popular and effective distance learning tools that can significantly increase the rates of students' perception of new information:

- the menti.com service allows you to create surveys and micro-assignments for students;

- the webinar.ru website allows not only to conduct highquality webinars, but also to mark up content, as well as highlight interesting places in lectures;

- the mindmeister.com website allows you to visualize various data and work on solving team problems.

At the same time, it is necessary to increase the efficiency of students' interaction, both with the teacher and among themselves, so that the distance learning process does not turn exclusively into the student's independent work [9].

Let us also note some facts.

1) Lack of online class skills among the teaching staff, especially in the 60+ age group. In Russia, the share of such teachers is quite high, despite the fact that they are 
professionals in their field, unfortunately, not all of them have developed digital skills, which are necessary for high-quality distance learning.

2) Fighting academic fraud and proctoring. Many higher education institutions in the 2020 summer session noted that student academic performance has increased significantly. In addition to the fact that students had the opportunity to study online, they also took exams and tests in a distance format. Many teachers complained that they did not have the opportunity to check the honesty of the students' answers, and also that it was impossible to evaluate, cheated the student or did the assignments themselves. To help combat academic fraud, some large Russian universities have introduced proctoring systems.

Proctoring refers to a system of face recognition and student behavior analysis, which allows you to monitor the examination online. During the testing, the identity of the student is confirmed, and possible attempts to falsify when passing the exam are recorded. The presence of a systematic assessment analysis enables the university to evaluate the student's response according to several criteria, which is a guarantor of the objectivity of the assessment. The introduction of a proctoring system in all Russian higher educational institutions will make it possible to check how honestly students pass exams.

Consider the main points that universities should take into account when introducing proctoring into their educational process:

- The presence of a system that allows distance education, for example, the Moodle system, which is present in the education system of many Russian universities, allows for successful proctoring. Although some systems, such as ProctorEdu, do not even need additional distance education systems.

- Consent to the use of students' personal data during the proctoring procedure.

- It is necessary to explain to students the importance of using proctoring, since most of them are not ready for this procedure for a number of reasons.

One of the important criteria for the successful implementation of the proctoring procedure in the higher education system is communication with students, the correct positioning of proctoring, as well as the compilation of detailed instructions for students.

\section{RESEARCH METHODS}

In this work, methods of sociological research, economic and mathematical, as well as structural and logical research methods were used. Analytical processing of various documents, regulations, decrees and laws was carried out. The main problems faced by higher educational institutions when introducing distance learning into the educational process are investigated, the pros and cons of distance learning are analyzed, and the most effective distance learning tools that can improve the perception of new information are considered. In addition, the study provides a forecast for the main trends in education, considers the prospects for blended learning, as well as the main goals and objectives that universities face during the "second wave of coronavirus" and after the exit from the pandemic.

\section{FINDINGS}

We will define the future of digital technologies in education, the main trends, consider the prospects for using digital technologies in Russian education, after getting out of the situation of forced distance learning. In this study, the emphasis is on what new should appear in universities when full-time education again becomes widespread and accessible.

Despite the fact that the period of self-isolation was quite short -4 months, all higher educational institutions were able to switch to a remote work format. Some universities made this transition systematic, while others, on the contrary, provided teachers with the opportunity to conduct online classes in a format convenient for them. The question is which of the universities will leave distance technologies in their educational process, and what proportion of distance technologies will be, in general, in the higher education system. This study was conducted with the aim of analyzing, to find out which distance technologies most effectively affect the perception of new information by students.

First, let's look at the main pros and cons of distance learning. (Table II) summarizes the advantages and disadvantages of distance learning, as well as its impact on students' perception of new information.

TABLE II. PROS AND CONS OF DISTANCE LEARNING, THE EFFECTIVENESS OF ITS INFLUENCE ON THE PERCEPTION OF NEW INFORMATION

\begin{tabular}{|l|l|}
\hline \multicolumn{1}{|c|}{ Pros of distance learning } & \multicolumn{1}{c|}{ Cons of distance learning } \\
\hline $\begin{array}{l}\text { Variability of using various formats } \\
\text { of distance learning (gamification, } \\
\text { online lectures, virtual simulators, } \\
\text { digital twins, etc.) }\end{array}$ & $\begin{array}{l}\text { Lack of control of the educational } \\
\text { process, the ability to turn off the } \\
\text { lecture and (or) mute the sound }\end{array}$ \\
\hline $\begin{array}{l}\text { The ability to transfer text } \\
\text { information in the format of visual } \\
\text { content }\end{array}$ & $\begin{array}{l}\text { Technical problems in distance } \\
\text { learning (lack of internet, lost } \\
\text { sound, video not working, etc.) }\end{array}$ \\
\hline $\begin{array}{l}\text { Convenience and flexibility of } \\
\text { learning for students, the ability to } \\
\text { complete assignments and listen to } \\
\text { lectures at a convenient time in a } \\
\text { comfortable environment }\end{array}$ & $\begin{array}{l}\text { Diffusion of audience attention, } \\
\text { dwitching between tasks, } \\
\text { distractions, decreased student } \\
\text { engagement in the }\end{array}$ \\
\hline $\begin{array}{l}\text { Savings in training costs such as } \\
\text { time savings }\end{array}$ & $\begin{array}{l}\text { Lack of digital literacy, both on the } \\
\text { part of teachers and students. }\end{array}$ \\
\hline $\begin{array}{l}\text { Formation of a digital environment, } \\
\text { continuous generation of interesting } \\
\text { content }\end{array}$ & $\begin{array}{l}\text { Lack of strict hierarchy in the } \\
\text { teacher-student system, loss of } \\
\text { power by the teacher, transition } \\
\text { from the status of "teacher" to the } \\
\text { status of "service provider" }\end{array}$ \\
\hline $\begin{array}{l}\text { Ease for the student in expressing } \\
\text { his thoughts and ideas, lack of fear } \\
\text { of public speaking. It's easier to } \\
\text { write your thought in online format }\end{array}$ & $\begin{array}{l}\text { Lack of netiquette criteria (time } \\
\text { accuracy, technical readiness, } \\
\text { correct background, etc.) }\end{array}$ \\
\hline
\end{tabular}

Let's consider the main goals of introducing distance technologies into the full-time educational process:

1) Introduction of an integrated approach to the educational process, in order to quickly adapt the educational process to the changing conditions of the external environment, by quickly switching between different learning formats. Such a switch in learning formats will create a stable educational environment without losing the rhythm of learning, without losing the quality of educational content. Thus, the key criterion for the effective work of a university is to easily combine any learning formats and quickly switch 
between them. The plus is that there are good prerequisites for the development of blended learning, since teachers and students have already mastered the basic skills of distance learning and are ready for blended learning. At the same time, it is necessary to constantly analyze big data and monitor the effectiveness of the educational process in order to quickly eliminate possible shortcomings. The introduction of an integrated approach to the educational environment will provide higher education institutions with the opportunity to ensure high performance indicators, regardless of changes in environmental conditions.

2) The introduction of digital technologies [10] will increase the speed of updating educational programs, which must respond quickly to the changing needs of the labor market in the professional competencies of students [11]. The plus is that there are good prerequisites for introducing digital technologies into the educational process, since today the implementation process has become an integral part of the work of any higher institution. HEIs need to constantly improve the learning environment and monitor the quality of digital content.

3) The global introduction of interactive educational technologies [12] will increase the involvement of students in the educational process and increase the efficiency of perception of new information [13]. In this case, I would like to note the importance of personalization, when each student can create his own convenient learning path for himself, build training in a convenient rhythm for himself, choose the content that interests him that corresponds to his professional and personal tasks.

4) Optimization of costs for training specialists. When setting this goal, optimization of time and financial costs is considered. This goal can be achieved through the use of blended learning formats. Unfortunately, the combination of online and offline formats is not a simple process, for this it is necessary to analyze the training, look specifically at each situation, what format of training will be optimal in each particular case, which will ultimately allow you to get the most efficiency from the educational process. The plus is that there are good prerequisites for optimizing costs, since many teachers and students noted the positive effect associated with saving time on the way from home to school, in large cities the time savings ranged from 2 to 5 hours a day. The financial costs of training have also been significantly reduced by saving money on travel, visiting catering places, and reducing the cost of office supplies and clothing. It would be fair to say that the modern education system has long been in need of optimization [14]. Particular attention should be paid to reducing the routine work of teachers associated with endless updates of work programs.

\section{CONCLUSION}

Despite the fact that initially the forced use of distance learning seemed to have some drawbacks, the study showed that the introduction of distance learning has both its advantages and disadvantages. The goal of effective learning is to achieve sustainable development of the educational process, this indicator can be achieved through the introduction of blended learning.
To increase the indicators of students perception of new knowledge, it is necessary to work on creating a digital educational environment, improve the quality of digital content, develop digital competencies of teachers and students, and also optimize all types of costs associated with learning.

\section{Acknowledgment}

The research was carried out within the framework of the grant project No. 16-29-12965\18 with financial support from the Russian Foundation for Basic Research.

\section{References}

[1] B.I. Tikhomirov, "Digital Transformations of Socio-Economic Development: a Thorny Path to a New Quality Information Society", Economics, taxes \& law, 2019, vol. 12(4), pp. 20-28. (In Russ.). DOI: 10.26794/1999-849X-2019-12-4-20-28

[2] C.E. Tømte, T. Fossland, P.O. Aamodt, and L. Degn, "Digitalisation in higher education: mapping institutional approaches for teaching and learning", Quality in Higher Education, 2019, vol. 25(1), pp. 98-114. DOI: $10.1080 / 13538322.2019 .1603611$

[3] T.S. Afanasyeva, and G.V. Fetisova, "Using the business KPI method as a means of students motivation", in The European Proceedings of Socia and Behavioral Sciences, 2019, vol. 59, pp. 916-923.

[4] J.J.M. Ferreira, C.I. Fernandes, and F.A.F. Ferreira, "To be or not to be digital, that is the question: Firm innovation and performance", Journal of Business Research, 2018, vol. 101, pp. 583-590.

[5] E.V. Laar, A.J.A.M. van Deursen, J.V. Dijk, and J.D. Haan, "The relation between 21st-century skills and digital skills: A systematic literature review", Computers in Human Behavior, 2017, vol. 72, pp. 577-588. DOI: https://doi.org/10.1016/j.chb.2017.03.010

[6] M.N. Pevzner, P.A. Petryakov, and N.A. Shaidorova, "Civic Education of University Students in the Context of Information Diversity", in The European Proceedings of Social and Behavioral Sciences, 2019, vol. 59, pp. 941-949.

[7] T.S. Afanasyeva, "New trends in the Russian university education: professional ethics and soft skills", in Proceedings of World International conference WYF Right to Dialogue, Italy, 2018

[8] S. Medvedev, "Teaching Online: Challenges and Opportunities of Digital Environment" [Prepodavanie onlain: vyzovy i vozmozhnosti tsifrovoy sredy]: VII Teaching Summer School, 2020. (In Russ.). Retrieved from https: //www.youtube.com/watch?v=vG9JANbnLXg\&list=PLihb10J69DrTawc 4Skur6X4yDSYPx0v0k\&index $=14 \& \mathrm{t}=0 \mathrm{~s}$

[9] V. Tretyakov, "Digital Technologies in Education" [Tsifrovye tekhnologii v obrazovanii]: VII Teaching Summer School, 2020. (In Russ.). Retrieved from https://www.youtube.com/watch?v=9_xXlzAs9Jc\&list=PLihb10J69DrTa 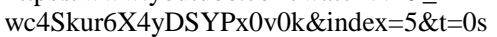

[10] V.N. Minina, "Digitalization of higher education and its socia outcomes", Vestnik of Saint Petersburg University. Sociology, 2020, vol. 13(1), pp. 84-101. (In Russ.). DOI: https://doi.org/10.21638/spbu12.2020.106

[11] V.A. Trifonov, and N.A. Shorokhova, "University Digitalization - A Fashionable Trend or Strategic Factor of Regional Development?", in The European Proceedings of Social and Behavioral Sciences, 2019, vol. 59. pp.1003-1013

[12] T.A. Subbotina, and E.F. Zhukova, "Digital Technologies and Their Role in Modern Economy of Russia", in The European Proceedings of Social and Behavioral Sciences, 2019, vol. 59, pp. 629-635.

[13] L. Castañeda, and N. Selwyn, "More than tools? Making sense of the ongoing digitizations of higher education", International Journal of Educational Technology in Higher Education, 2018, 15:22. DOI: https://doi.org/10.1186/s41239-018-0109-y

[14] C. Loebbecke, and A. Picot, "Reflections on societal and business model transformation arising from digitization and big data analytics: A research agenda", The Journal of Strategic Information Systems, 2015, vol. 24(3), pp. 149-157. 